\title{
A arte de disciplinar os sentidos \\ o uso de retratos e imagens em tempos de nacionalização (1930-1945)
}

\author{
ROGÉRIO LUIZ SOUZA \\ Universidade Federal de Santa \\ Catarina, Florianópolis, SC, Brasil
}

RESUMO

Toda a arquitetura sensitiva do Estado Novo, ao chamar a atenção permanente dos sentidos, quis tornar os sujeitos consumidores e reprodutores de uma representação de mundo, de uma crença em relação à identidade nacional brasileira. Sob o império dos sentidos disciplinados e habituados, essa mesma arquitetura acabou permitindo um "sentir brasileiro" que levou os sujeitos a experimentá-lo, saboreá-lo, tocá-lo, ouvi-lo, cheirá-lo e vê-lo no interior de um sistema cultural e simbólico construído pela maquinaria ordenadora do poder. A constituição de uma arquitetura sensitiva no espaço escolar - objeto de discussão e análise deste artigo - deveria ajudar a compor essa trama nacionalizadora e a promover a disciplinarização dos sentidos. As ritualizações e as técnicas de reprodutibilidade das imagens nesse espaço tiveram a função de divulgar, generalizar, uniformizar, habituar e manter os sentidos em alerta constante e, portanto, ligá-los, condicioná-los ao sistema de controle político-social.

\section{PALAVRAS-CHAVE}

arquitetura sensitiva; disciplinarização dos sentidos; espaço escolar; imagens; Estado Novo. 


\title{
THE ART OF DISCIPLINING THE SENSES: THE USE OF PICTURES AND IMAGES IN TIMES OF NATIONALIZATION (1930-1945)
}

\begin{abstract}
The entire architecture of sensitiveness by Estado Novo, by calling constant attention to the senses, aimed at turning subjects into consumers and reproducers of a representation of the world, of a belief in relation to the brazilian national identity. Under the realm of senses which were disciplined and conditioned by habit, such architecture eventually led to a "brazilian way of perceiving" which led subjects to experience, taste, touch, hear, smell and see it within a cultural and symbolic system developed by the organizational machinery of the established power. The constitution of an architecture of sensitiveness in the school space - the object of discussion and analysis in this article - should help compose this nationalization scheme and promote the disciplining of the senses. The rituals and techniques to reproduce images in this space had the function of propagating, generalizing, unifying, accustoming the senses to being constantly alert and, therefore, connecting and conditioning them to the political and social control system.
\end{abstract}

\section{KEYWORDS}

architecture of sensitiveness; disciplining of the senses; school space; images; Estado Novo.

\section{EL ARTE DE DISCIPLINAR LOS SENTIDOS: EL USO DE RETRATOS E IMÁGENES EN TIEMPOS DE NACIONALIZACIÓN (1930-1945)}

\section{RESUMEN}

Toda la arquitectura sensitiva del Estado Nuevo, al llamar la atención permanente de los sentidos, quiso tornar los sujetos consumidores y reproductores de una representación del mundo, de una creencia en relación a la identidad nacional brasileña. Bajo el imperio de los sentidos disciplinados y habituados, esa misma arquitectura acabó por permitir un "sentir brasileño" que llevó a los sujetos a probarlo, saborearlo, tocarlo, oírlo, olerlo y verlo en el interior de un sistema cultural y simbólico construido por la maquinaria ordenadora del poder. La constitución de una arquitectura sensitiva en el espacio escolar -objeto de discusión y análisis de este artículo- debería ayudar a componer esa trama nacionalizadora y a promover la disciplina de los sentidos. Los rituales y las técnicas de reproductibilidad de las imágenes en ese espacio tuvieron la función de difundir, generalizar, uniformar, habituar y mantener los sentidos en alerta constante, por lo tanto, conectarlos y condicionarlos al sistema de control políticosocial.

\section{PALABRAS CLAVE}

arquitectura sensitiva; disciplina de los sentidos; espacio escolar; imágenes; Estado Nuevo. 
Iniciamos esta discussão dizendo que a política de nacionalização do início dos anos 1930 no Brasil e do período subsequente, denominado Estado Novo, estava comprometida com um projeto que visava, entre outras coisas, à regeneração social e à recondução dos sujeitos a uma postura de identificação com determinados paradigmas de brasilidade. Esse projeto quis imprimir nos sujeitos uma facticidade subjetiva, ou seja, quis criar valores e projetos de vida que deveriam aparecer como realidade única na concretização de uma nova nação e na consciência individual. Ao querer fazer o Brasil renascer das cinzas da República Velha, os representantes e agentes da política estado-novista adotaram estratégias de construção de novos significados e, diante da precariedade notória da nova ordem política, estimularam a ritualização de práticas sociais e a disciplinarização das condutas. O que estava em jogo era a depuração da consciência individual a fim de que os sujeitos fossem conduzidos por uma pretensa coletividade uniformizada e arraigadamente vinculada às aspirações das suas instituições. O decisivo aqui "era que as reações do indivíduo fossem condicionadas desde o início pelo caráter coletivo dessa reação. $\mathrm{E}$ ao mesmo tempo em que essas reações se manifestassem, elas se controlariam mutuamente" (Benjamim, 1994, p. 188).

De certa maneira, essa tarefa foi bem-sucedida porque esteve inscrita numa mecânica que parecia ser natural e porque sua comunicação simbólica arrastou os sujeitos a verem os desejos, os anseios e os medos dos agentes do Estado como efeitos de uma tendência interior.

Nos anos dessa longa ditadura simbólica, se quis, portanto, a atenção permanente dos sentidos. Não é mesmo possível dizer da docilidade, da aptidão e da dominação do corpo e da mente dos sujeitos nesse período da história brasileira sem antes falarmos sobre o investimento cotidiano nos sentidos.

A arte de disciplinar repousa também nos sentidos. Afinal, somos, por meio dos sentidos, capazes de capturar o mundo em suas dimensões materiais e simbólicas e de apreender a intencionalidade do ordenamento das coisas sem, contudo, ter necessariamente de compreendê-las em seu ordenamento, sendo suficiente tê-las como elementos normais do espaço coletivo, porque, sem essas coisas em nosso entorno, tudo parece ser estranho e não ter sentido. Isso quer dizer que, conforme a concepção do conhecimento sensível trazida pela fenomenologia, percebemos pelos sentidos uma forma que é sempre organizada e estruturada e que nos oferece um acesso ao mundo dos objetos práticos e instrumentais, orientando-nos para a ação cotidiana.

Além disso, o modo pelo qual se organiza a percepção humana e o meio em que ela se dá são também condicionados historicamente. Essa percepção é, pois, um conhecimento sensorial das coisas dotadas de sentido e significações históricas e uma forma de ação fundamental para a vida. E o habitus que é permitido e oferecido pelos sentidos - a condição ativa dos sentidos -, assim como a percepção que se efetua pelo hábito por causa exatamente da força repetitiva de um contexto, por exemplo, arquitetônico sensitivo - a condição passiva dos sentidos -, dá segurança e tranquilidade ao nosso esforço de nos sentir integrados e reconhecidos pela sociedade. Os sentidos nos habituam, ou melhor, ajudam-nos a nos sentir habituados e integrados, de tal maneira que aquele que anda distraído, diante das técnicas de reprodutibilidade, pode 
habituar-se. Essa condição ativa e passiva dos sentidos é tão importante e necessária quanto a reflexão, e, por isso, é objeto e alvo do poder.

Desde o século XVIII, a modernidade vem construindo uma arquitetura sensitiva com o propósito de imprimir nos sujeitos uma forma de sentir, perceber e ter sensibilidade. A vontade e a atenção dedicadas pelo poder aos sentidos estão ligadas geralmente ao aprofundamento da sujeição a determinados valores, à normalização dos espaços e ao ordenamento do mundo.

Assim, parece ser sintomático que em tempos de repressão e autoritarismo como aquele do período estado-novista brasileiro - os sentidos estejam sendo limitados por um número reduzido de símbolos, imagens e experiências, e que, ao mesmo tempo, estejam sendo esses mesmos símbolos, imagens e experiências apropriados, monopolizados, uniformizados e exaustivamente expostos e reproduzidos. Por isso, orientar os sentidos dos sujeitos em razão de uma realidade sequestrada ou fabricada por objetos e imagens carregados de sentido e intencionalidade é um processo de imenso alcance a serviço dos regimes totalitários. Walter Benjamim (idem, p. 170), ao escrever sobre a obra de arte na era de sua reprodutibilidade técnica, em 1935-1936, tinha presente que

fazer as coisas "ficarem mais próximas" era uma preocupação tão apaixonada das massas modernas como sua tendência a superar o caráter único de todos os fatos através da sua reprodutibilidade. Cada dia fica mais irresistível a necessidade de possuir o objeto, tão perto quanto possível, na imagem, ou antes, na sua cópia, na sua reprodução. [...] Assim se manifesta na esfera sensorial a tendência que na esfera teórica explica a importância crescente da estatística. Orientar a realidade em função das massas e as massas em função da realidade é um processo de imenso alcance, tanto para o pensamento como para a intuição.

O impulso criativo, dessa maneira, aparece quase sempre para estetizar e espetacularizar a política ou, inversamente, para dissimular sua resistência e oposição. ${ }^{1}$ Em tempos em que o afrouxamento dos impulsos repressivos da sociedade tende à multiplicidade de vontades, os sentidos estão abertos a um número maior e ilimitado de símbolos, imagens e experiências concorrentes, assim como o impulso criativo está associado às diferentes sensibilidades, simulando, muitas vezes, uma resistência e uma oposição à ordem. Não se trata de cotejar aqui essas temporalidades diversas naquilo que podem ter de próprio e de diferente, mas de somente chamar a atenção para o fato do uso dos sentidos como mecanismo de disciplina.

Manter a sociedade brasileira do período estado-novista dentro de uma mesma dinâmica ou ritmo sensitivo exigiu mais que técnicas minuciosas e sub-reptícias de controle e vigilância, requereu a exteriorização objetiva, crua e intencional daquilo

1 Pensamos aqui em Graciliano Ramos, Carlos Drummond de Andrade, Cândido Portinari, Martinho de Haro, Pixinguinha, Ismael Silva, Noel Rosa e, já na fase final do Estado Novo, João Cabral de Melo Neto, Guimarães Rosa e Clarice Lispector. 
que se quis ordenar sem, contudo, abrir para o campo da reflexão e da crítica. O que se desejou foi alçar diretamente pelos sentidos um nível de racionalidade ou conhecimento sobre as coisas cujo processo se deu pela monopolização e repetição, quase que única e amplamente divulgada, de imagens e narrativas estruturantes da vida. Portanto, elevar os sentidos, que estavam sendo habituados por um sistema disciplinar de repetição, a uma racionalidade era querer tornar os sujeitos cúmplices de um mesmo empreendimento e atrelados a uma mesma crença, na qual todos trabalhariam para promover, divulgar e fazer a propaganda daquilo que devia ser consumido por todos.

Ao compreendermos o Estado Novo dentro de uma lógica de dominação e de produção de crenças, parece certo também o perceber como criador de uma emergência epistêmica pelos sentidos e, portanto, criador de uma nova forma de percepção - sensação, em vista da reprodução da ordem social e da permanência das relações de dominação. Reconhece-se, enfim, nos sentidos permanentemente controlados, vigiados, adestrados e habituados, uma força de coesão social. Nos versos da canção de Noel Rosa, Três apitos, de 1933, podemos perceber os contornos dessa arquitetura sensitiva estado-novista que quis habituar, ordenar e condicionar os sentidos e, portanto, a própria percepção em relação ao mundo do trabalho:

Você que atende ao apito/ de uma chaminé de barro/ por que não atende ao grito tão aflito/ da buzina do meu carro?/ [...] Quando o apito/ da fábrica de tecido/ vem ferir os meus ouvidos/ eu me lembro de você/ [...] Mas você não sabe/ que enquanto você faz pano/ faço junto do piano/ estes versos pra você.

Os efeitos de dominação obtidos com a disciplinarização dos sentidos são aqueles que, para serem exercidos, não precisam de elementos reflexivos como os das palavras, mas sim do silêncio cúmplice ao ouvir, por exemplo, o apito de uma fábrica de tecido chamando para o trabalho. $\mathrm{O}$ som desse apito pode ferir os ouvidos de um compositor-artista, mas a ordem definida por esse mesmo som para uma operária é outra. Ela caminha em direção àquele som e não atende "ao grito tão aflito" de outros sons. Ela passa, então, a ser "cúmplice" de uma arquitetura sensitiva, pois manifesta e compartilha mutuamente uma mesma reação - o caminhar em direção ao som do apito - que será percebida, pelos outros que observam, como um movimento único e coeso, como uma imagem cheia de significações que habitua os sentidos a reconhecerem naquele ordenamento uma naturalidade. Essa cumplicidade silenciosa e essa naturalização são alçadas pelos sentidos porque não se precisa dizer, basta apenas sentir. O próprio compositor-artista, ao capturar esse ordenamento, reconheceu a objetividade nua e estética dessa arquitetura sensitiva, à qual, talvez, mais que resistir, ele não teria conseguido se sentir integrado diante de uma realidade que parecia representar a ordem natural das coisas. $O$ apelo sensitivo não foi o bastante para habituar seus sentidos e tampouco sua canção ajudou a desconstruir a lógica interna dessa arquitetura sensitiva. Noel Rosa engavetou sua canção, que recebeu seu primeiro registro apenas em 1951, na voz de Aracy de Almeida (Máximo; Didier, 1990). Coube, no entanto, a um significativo número de autores sociais instaurar, naquele contexto estado-novista, um universo de reações sensitivas e de representações simbólicas e estruturantes do 
real como plausível e desejável em sua intencionalidade, sem ter necessariamente de entendê-lo em seu ordenamento, a ponto de se sentir também encantado com aquela arte disciplinadora do viver e do sentir a vida.

No período do Estado Novo, quando falamos da vontade de querer disciplinar ou habituar os sentidos, estamos querendo falar também do desejo daqueles sujeitos de se sentirem integrados num mesmo habitus, mesmo se considerarmos as regras absurdas e suas perspectivas enganosas. Nesse habitus, a impressão é de que não se pode modificar ou substituir nenhuma peça da arquitetura sensitiva. Entendemos que essa arquitetura sensitiva foi capaz de instituir uma crença, uma promessa, de comportar valores e normalizar os espaços e o tempo - o passado e o futuro em virtude daquele presente. Para isso, foi preciso ensinar os privilégios do sentido, do vivido, do carnal, da experiência e, por extensão, das significações sociais para tornar a realidade essencial, fixa e monumental. E assim cada imagem dessa nova arquitetura sensitiva foi pesada, como os lugares que ela ocupou, fixando-se como memória por meio de uma disciplina dos sentidos, da percepção efetuada pelo hábito. Isso gerou um verdadeiro sistema ordenador e regulador da vida, tornando-se - por firme autocontrole dos sujeitos ou elevado automatismo - cada vez mais estável, uniforme e generalizado. Cabe salientar que a imagem suficientemente reconhecível pelos efeitos da sua "repetitividade" e reprodutibilidade mostra, pois, a coisa sempre em sua valoração, significação e intenção. É, portanto, uma linguagem própria que contém armadilhas e uma função prática e social de ordenamento.

Toda a arquitetura sensitiva do Estado Novo, ao evocar os sentidos, quis tornar os sujeitos consumidores e reprodutores de uma representação de mundo, de uma crença em relação à identidade nacional brasileira. E, sob o império dos sentidos disciplinados e habituados, essa mesma arquitetura acabou permitindo um "sentir brasileiro" que levou os sujeitos a experimentá-lo, saboreá-lo, tocá-lo, ouvi-lo, cheirá-lo e vê-lo no interior de um sistema cultural e simbólico construído pela maquinaria ordenadora do poder. A utilização de imagens teve, pois, a intenção de espalhar, como afirma Alcir Lenharo (1986, p. 16), em sua obra $A$ sacralização da política, "uma carga emotiva e sensorial, de modo a atingir facilmente o público receptor, detonando respostas emotivas que significassem, politicamente, estados de aceitação, contentamento, satisfação - reações passivas e não críticas".

Podemos por analogia dizer, então, que alcançar os sentidos era alcançar - logo em seguida e de igual modo - o corpo, para habituá-lo e torná-lo tanto mais obediente quanto mais útil fosse. Em assim sendo, conforme Michel Foucault (1987, p. 127), tratava-se de formar uma "política de coerções que são um trabalho sobre o corpo, uma manipulação calculada de seus elementos, de seus gestos, de seus comportamentos" e, para nós, de uma manipulação calculada de seus sentidos ou percepções. Isso quer dizer também que a arquitetura sensitiva estimula e transmite complicados sinais convencionais e codificados, passíveis de serem interpretados e refletidos, não resta dúvida; mas que são evocados amiúde, nesse contexto autoritário, com o objetivo limitado de serem capturados única e instantaneamente pelos sentidos ao se rarefazer a dimensão reflexiva. Podemos dizer, desse modo, que o mundo dos sentidos não é 
um estado ou condição inferior do sujeito do conhecimento, mas um estado de sujeição muitas vezes provocado por aqueles que, no exercício de poder, querem anular a condição autônoma e reflexiva do sujeito do conhecimento.

A questão que logo nos vem, então, é sobre como é possível manter os sujeitos nesse estado de sujeição sensitiva, pois esses mesmos sentidos, ligados que estão por uma compreensão filosófica ao mundo do impulso e dos instintos, não estariam, por si só, desligados dos sistemas de controle, resistindo?

Nesse caso, a ação disciplinar dos agentes institucionais do Estado Novo acaba se justificando tanto pela necessidade de manter os sentidos em alerta constante quanto pela necessidade de ligá-los aos sistemas de controle, sujeitando-os à vigilância sistemática e à repressão efetiva. $\mathrm{O}$ processo de sujeição passa, pois, pela domesticação e pelo autodomínio dos sentidos por meio da percepção de uma arquitetura sensitiva normalizada, repetida e ritualizada permanentemente. E a emergência ou começo dessa arquitetura sensitiva estado-novista talvez esteja tão voltada ao seu aparato ritualístico e imagético quanto às suas próprias estruturas físicas. Porque a prática ritual faz parte do jogo de poder, do domínio social, sugerindo aos sentidos no processo de domesticação e de habituação as imagens recorrentes que tornam essenciais determinados valores e cristalizam um imaginário de unidade e, por corolário, de brasilidade.

O espaço do rito faz crer, pois, que a criação da sociedade ou da nação, nesse caso, nasce e depende da própria vontade do sujeito. $\mathrm{E}$, a partir daí, esse sujeito se vê inserido na construção de um mundo referendado por um rito que se repete várias vezes e faz uso de imagens e gestos para imprimir nos sentidos os sinais convencionados que devem funcionar como elementos exclusivos na interpretação dos anseios maiores da nação, apontados pelo regime autoritário do Estado Novo. E assim é que, ao encontrá-los inscritos no meio da praça, nas ruas, nas paredes dos salões nobres e das casas e, enfim, na multiplicidade de tantos outros espaços públicos e privados, reconhece-se não apenas uma tendência estética, mas uma intenção política.

A força "arregimentadora" do espaço ritual e daquilo que ficou aureolado após seu descerramento - o próprio sinal visível e cheio de significações dos quadros, retratos, painéis, placas, bustos, estátuas - disciplina e habitua os sentidos dos sujeitos por um conjunto limitado de imagens. Esse sistema de regras e valores fixos é capaz não somente de aglutinar e de chamar a atenção para si, mas de estabelecer uma ética única, entre aquela situada no espaço doméstico e aquela, agora arquitetada por um sistema ritual sensitivo, no espaço público, visando à unificação de um sistema social no qual espaço doméstico e espaço público seriam vistos como uma realidade totalizante.

Nesse sentido, os ritos públicos de caráter geralmente cívico-religioso, mais que criar uma ética a ser assumida no espaço social comum, inventaram e fabricaram imagens que referenciavam uma ética uniforme a ser válida também para os sujeitos no espaço privado e naquele mesmo espaço público que deixou de sofrer a intervenção direta do rito. Ou seja, a ética dos sistemas espaciais ou, em outros termos, a ética daquela arquitetura sensitiva em seu contexto de reprodutibilidade e que se impôs a olhos vistos pelo conjunto de imagens ou de suas representações pressupôs a ética criada pela imagética do rito, numa relação indissolúvel entre os princípios de 
responsabilidade pelo bem coletivo e os de realização pessoal. E esse conjunto, pois, de imagens, dizem Chaui e Franco (1979, p. 46), foi um

[...] espelhamento ampliado e iluminado da experiência imediata, dotadas da capacidade de unificar aquilo que nesta última aparece fragmentariamente. Unindo o disperso, a imagem, espelho dos dados imediatos, exclui a reflexão e, simultaneamente, cria a ilusão de conhecimento, graças ao seu aspecto ordenador.

Isso nos ajuda a pensar que na domesticação ou na disciplinarização dos sentidos estimula-se e fabrica-se, pois, um senso estético que leva os sujeitos a se sentirem competentes e autônomos ao reafirmar e reproduzir seus elementos, seus códigos, seus gestos. Esse controle de si, experimentado ou sentido como uma opção ou escolha, sedimenta a convicção de que os sujeitos têm um papel ativo no mundo e que podem ser úteis e importantes. Essa sensação não é senão a exteriorização de competências comportamentais habituadas ou adestradas que se tornam essencialmente um "valor de mercado".

O silêncio cúmplice, do qual falamos anteriormente, modela-se aqui, pois se exige mais dos sentidos que da reflexão. Coube à arquitetura sensitiva do Estado Novo, em sua reprodutibilidade, objetividade e conteúdo essencial, a tarefa de ser também um autor social por excelência. Nela se percebe a ação personificada do falar e do ouvir. E, nesse caso, podemos dizer que são as suas próprias paredes, com suas imagens suspensas e retratos dependurados, que parecem ouvir e, portanto, reunir a força ordenadora dos discursos dispersos, fragmentados - e, em nome dessa força, parecem falar para os sujeitos como intérpretes qualificados dos sentidos, das significações e do conteúdo essencial daquela nova epistème. E isso se multiplica, isso se repete e se imita, circula e ganha uma dimensão gigantesca, enchendo os espaços públicos e privados, invadindo a cotidianidade e transformando-se num imenso corpo cheio de desejos, vontades e medos. A arquitetura sensitiva diz para os sentidos dos sujeitos o lugar que eles devem ocupar na sociedade. Portanto, a capacidade formativa daquela arquitetura pulsante moveu as pessoas, aprofundou a sujeição dos sentidos, instituiu um senso estético e limitou a postura reflexiva, porque, entre outras coisas, manteve seu aspecto repetitivo e uniforme.

O que estava em jogo, sabemos, era a construção de um sentimento pretensamente único de brasilidade em vista de uma nacionalidade que fizesse frente à heterogeneidade étnica, ao regionalismo político e à falta de uma unidade econômico-cultural. E ter presente a brasilidade nos e pelos sentidos era um exercício disciplinar cotidiano que entrava nas estratégias de reprodução, repetição, controle, vigilância e punição estado-novista. Tanto os momentos solenes ligados ao sistema ritual sensitivo de entronização do crucifixo nos tribunais do júri, ou a inauguração de um retrato no espaço escolar, ou a exposição de um quadro em um museu de arte, ou o descerramento de um mural no hall de entrada de uma repartição pública, como a proliferação de quadros, retratos e imagens nas paredes do espaço privado de casas ou bares, mercearias e pequenos estabelecimentos comerciais nos revelam a estreita relação entre a propaganda estado-novista e o uso que se fez dessas imagens e retratos. Seja um 
quadro como o Depois do rodeio, de Martinho de $\mathrm{Haro}^{2}$ (Prêmio Nacional Viagem ao Exterior, 1938) - verdadeiro flagrante regionalista do tipo local e documento de costume brasileiro, que se associa a Mocinha do suburbio, Tropeiros, Chimarrão, Mulata e Baile do postinho, da mesma fase do pintor e que remete, por sua apropriação como obra premiada, aos elementos fortes do traço regionalista brasileiro do então presidente da República, Getúlio Vargas -, seja o retrato de uma numerosa família atestando na parede de um lar o matrimônio monogâmico indissolúvel para a procriação da prole saudável; tudo isso indica a condição estratégica de disciplinarização dos sentidos por uma arquitetura sensitiva tanto do ambiente público quanto do doméstico, nos quais os sujeitos se encontram, participam, reproduzem e consomem como sendo seus.

O importante a destacar é que a dinâmica dessas imagens tanto afirma um paradigma a ser consumido e com o qual se habitua, como faz indicar, para além das fronteiras dos quadros e retratos, aquilo que se deve negar e que se deve de ter medo no mundo real. Nesse caso, as imagens - ao se tornarem familiares aos sujeitos pela percepção dos sentidos controlados e por esgotarem nelas mesmas uma unidade e totalidade epistêmica das significações e intenções fragmentadas das práticas e dos discursos - saltam de suas molduras, metamorfoseiam-se em corpos cheios de desejos e medos, respondem a um ordenamento social, discriminam os corpos e os espaços de acordo com a perfectibilidade inventada e repetida, limitam a postura reflexiva e habituam os sentidos a uma forma de perceber e conhecer o mundo.

Para nós, os efeitos de dominação dos sentidos pela arquitetura sensitiva são, portanto, de duas ordens: uma interna, porque aprofunda a sujeição ao domesticar os sentidos para uma única e determinada direção e experiência do real, e uma outra, externa, porque prepara o sujeito para identificar o que torna nocivo à ordem, àquela mesma definida pela arquitetura sensitiva do ambiente.

\section{O ESPAÇO ESCOLAR E A ARTE DE DISCIPLINAR OS SENTIDOS}

A capacidade, pois, formativa dessa arquitetura é encontrada, como já dissemos, em todos os lugares, invadindo a cotidianidade e tomando corpo. Não se trata aqui de fazer a história de todos esses lugares, no que podem ter cada um de singular, mas de localizar apenas um exemplo desse processo disciplinar dos sentidos. Vamos situá-lo - e nada é mais óbvio - num espaço escolar, já que nesse espaço o sujeito em sua fase impressionável - a infância, a adolescência e a juventude - se vê absorvido completamente por mecanismos controladores de sua personalidade em formação. O que, em suma, significa dizer ou fazer acreditar na possibilidade de uma aprendizagem de autocontrole dos impulsos e emoções, desde que se saiba direcionar, domesticar, disciplinar, controlar, habituar e, enfim, automatizar os sentidos. Isso, como

2 Pintor, desenhista e muralista brasileiro, Martinho de Haro iniciou-se na pintura em Lages, Santa Catarina. Estudou na Escola Nacional de Belas Artes, Rio de Janeiro, de 1927 a 1937. Viajou a Paris em 1938, onde estudou com Otto Friez. Retornou ao Brasil em 1939, permanecendo em Florianópolis até o final de sua vida, em 1985. 
sabemos, comporta dor e deixa cicatrizes. O balanço positivo que se quer imprimir é o estabelecimento de um padrão de conduta bem-sucedido, adaptado e habituado às pressões e tensões do contexto social. O "valor de mercado" que isso carrega exige do sujeito em formação uma competência comportamental e, portanto, sensitiva que lhe será benéfica nas relações de aparência, de poder e de saber, mas que também the dará a visão mais exata de si e dos demais, em vista da posição social em que se está ou pretende estar.

O espaço escolar fazia parte do processo de nacionalização. Depois da vitória dos "revolucionários" de 1930, o governo varguista teve pressa em enterrar o passado liberal. Para que isso fosse possível, o Estado contou com um aparato de divulgação e habituação dos sentidos que extrapolou a esfera da propaganda política e emaranhou-se nas instituições e no cotidiano das pessoas. Não bastava o triunfo, era preciso persuadir e convencer a todos da disposição dos agentes estatais em construir uma pátria ordeira e genuinamente brasileira. As instituições escolares deveriam defender esse propósito e se constituir como instrumentos de viabilização desse nacionalismo. A autêntica escola seria aquela que condenaria o individualismo e promoveria os sentimentos nacionais. Segundo José Antônio Tobias (1986, p. 313),

o ponto de partida para a educação brasileira conseguir acertar na procura de autenticidade e de brasilidade era abandonar, o mais cedo possível, o tradicional e espalhado vício da imitação servil e humilhante do estrangeiro. Para se conseguir autenticidade era necessário colocar-se num nacionalismo distante do individualismo.

Colocar a instituição escolar em primeiro plano era, portanto, a condição necessária para superar o complexo de inferioridade. Disso nascia o incontido desejo de agrupar tudo e todos numa mesma finalidade social e patriótica. A educação escolar existiria para formar o educando dentro dos princípios do corpo social hierarquizado, definido pelo Estado.

A reforma de Francisco Campos (1931) e a reforma de Gustavo Capanema (1942) para a educação brasileira apontaram para essa direção e garantiram, pela primeira vez no Brasil, uma organização e um método comum para todas as escolas públicas e particulares, com o controle do Departamento Nacional de Educação.

Nacionalizava-se o ensino!

A ação da escola deveria influenciar o educando de tal maneira que o envolvesse e o penetrasse de civilização, a fim de torná-lo membro ajustado do corpo social. A finalidade fundamental do ensino seria, portanto, formar a personalidade, adaptar o ser humano às exigências da sociedade, socializá-lo, habituá-lo. Segundo Nóbrega (1952, p. 311), o ensino secundário, para Gustavo Capanema,

teria mais precisamente por finalidade a formação da consciência patriótica. $\mathrm{O}$ ensino secundário se destinaria à preparação dos homens que deveriam assumir as responsabilidades maiores dentro da nação, dos homens portadores das con- 
cepções e atitudes espirituais que era preciso infundir nas massas, que era preciso tornar habituais entre o povo.

Todos deveriam cooperar, negando-se a si mesmos, em prol do "povo-uno". Opor-se a isso era cair numa indeterminação de identidade, num individualismo, tornando-se um "outro" fora da relação social. Todo o sistema escolar deveria ser responsável pelo autodomínio das paixões humanas e de um tipo ideal identificado com as estruturas sociais - um sujeito homogeneizado, fabricado pelo discurso nacionalista e habituado a uma arquitetura sensitiva própria, que ultrapassaria as letras e que se esperava transformar em realidade concreta. $\mathrm{O}$ controle social tinha que começar desde cedo, educando e alertando a criança e o jovem para o perigo a que estavam sujeitos, para que não se tornassem futuros traidores da pátria, pervertendo a moral e os bons costumes. Tinha-se pressa em habituar os sentidos deles e formar "o coração da criança, desde tenra, desde o lar, e desde a escola, pelos princípios da austera, da verdadeira moral, ensinando-lhe o que lhe incumbia, atingindo o necessário desenvolvimento, para consigo, para com o próximo e para com a pátria” (Oliveira, 1920, p. 12).

Nos colégios católicos e nas escolas públicas, a instrução deveria revestir-se de referenciais cívico-religiosos. O Ginásio Catarinense, considerado um dos melhores estabelecimentos escolares do Brasil, tinha também sua importância nesse processo de formação dos sentidos dos sujeitos e, é claro, no processo de nacionalização. Passou mesmo de ginásio para colégio por força do decreto-lei n. 11.235, de 6 de janeiro de 1943, em pleno Estado Novo. Desde então denominado de Colégio Catarinense instituição escolar da Companhia de Jesus, que por cem anos vem oferecendo ensino, quase sempre, aos filhos da elite letrada e dirigente do estado de Santa Catarina -, iniciou suas atividades escolares em 15 de março de 1906. Sua emergência, em regime de internato e externato masculino, vinha de certa ineficácia do governo catarinense em garantir um instituto de ensino secundário público e da vontade da hierarquia católica em assegurar um colégio sem as feições liberais da Primeira República.

O Colégio Catarinense, portanto, não poderia deixar de estar situado nesse contexto de reformas político-educacionais do Estado Novo. Suas portas não haviam sido fechadas. $\mathrm{O}$ processo de nacionalização, que se efetivara e se impusera a esse mundo escolar em particular, tirou da direção dos jesuítas, é certo, a autonomia e a definição dos conteúdos curriculares, mas lhes assegurou um lugar de destaque. Afinal, sua alma cristã, seus moços, seu esforço pelo regramento, sua adesão ao projeto nacional confirmavam e tranquilizavam o governo federal. Era entendido como um aparelho óptico capaz de divisar o futuro. Como instituto secundário, era um mecanismo importante e influente para promover os ideais nacionais entre uma mocidade masculina que deveria assumir as responsabilidades maiores dentro da nação. Segundo o inspetor federal, o Colégio Catarinense não era somente um estabelecimento de estudo, mas, em verdade,

era uma grande casa de família onde todos se dedicavam a uma só finalidade que era a de preparar jovens para serem dignos da sociedade e que pudessem ingressar na vida prática com sólidos conhecimentos culturais, religiosos e 
sociais. Não saíam tontos, porque iam fortalecidos pela fé. (Ginásio Catarinense, 1940, p. 39)

Esses moços deveriam estar ligados a um empreendimento social, visando à "grandeza do Brasil". Para se alcançar esses propósitos, três foram os imperativos pedagógicos que guiaram a ação educativa dos padres do colégio naquele momento de ebulição nacionalista: "sujeita-te”; "esforça-te”; e "domina-te"(Ginásio Catarinense, 1933, p. 53). Os alunos deveriam guardar à risca até as pequenas prescrições disciplinares, de si próprias insignificantes, mas que se impunham com positiva necessidade aos alunos que queriam se educar, isto é, aprender a obedecer e prezar a autoridade e as ordens dos seus prepostos.

A "revolução" de 1930 inaugurara um momento emergencial, uma nova era, na qual se queria prever os efeitos e garantir a estabilidade social, longe de qualquer alteridade estranha ao regime e ao "bom encaminhamento social". Os sujeitos deveriam internalizar os valores capazes de proporcionar a verdadeira engenhosidade humana. Era o momento da introspecção de valores inventados, nos quais supostamente se estaria realizando a rememoração das raízes nacionais. De nada valeriam as tecnologias, a ciência e a educação, se os sentidos não estivessem voltados para uma mesma percepção da realidade e, portanto, habituados a "olhar" em uma mesma direção. Essa nova civilização que se construía deveria levar em conta a integração incondicional da mocidade e a disciplina físico-moral de seu corpo e de seus sentidos, habilitando-a, antes de tudo, ao serviço da pátria. Os que se afastassem deveriam ser excluídos da relação social, pois subvertiam a ordem e negavam as práticas regulamentares do agir uniformizado. Portanto, as instituições escolares, como o Colégio Catarinense, deveriam servir para enquadrar os ineptos e adaptá-los à sociedade que se desejava. Era bem claro o objetivo estado-novista: queria-se forjar um sujeito ideal; uma mocidade ideal comprometida com o corpo social; um tipo ideal capaz de suplantar as incorreções morais e as imoderações do ambiente profano; um tipo ideal, reconhecidamente cristão, saudável e virtuoso. E, enquadrada nessa perspectiva, a mocidade do colégio era convocada a se engajar no novo empreendimento civilizatório.

Dentro do contexto da política de nacionalização que se estendeu até 1945, o modelo pedagógico implantado no Colégio Catarinense exigira o reconhecimento de uma autoridade, o sacrifício pela edificação da pátria, a "invenção" e apropriação de uma brasilidade e a internalização de valores ético-cristãos considerados capazes de reordenar as condutas sociais e de perspectivar um projeto nacionalista. A busca por um corpo são e uma alma sã exigia de todos a vigilância constante dos hábitos e dos costumes cotidianos. O cultivo da virtude cristã era a condição sem a qual não haveria o progresso da nação. Por isso mesmo, os professores e os padres prefeitos do colégio assumiam o papel de formadores das noções higiênicas e morais da mocidade.

Entendiam que a realização dessa mocidade centrava-se, pois, na adaptação dela a um meio social cristão.

O Colégio Catarinense ufanava-se por ver entre as fileiras nacionais discípulos seus, que outrora honraram os bancos escolares. A semente lançada produziu os 
desejados frutos. Mestres e prefeitos do Catarinense não deixaram de incutir em seus educandos, a par da ciência, o amor incondicional aos supremos ideais da religião e da pátria. (Colégio Catarinense, 1944, p. 9)

As comemorações cívico-religiosas no colégio revelam, pois, a montagem arquitetônico-sensitiva e as intenções de um projeto e uma prática nacionalista. Ritualizando um sistema comum de crenças e de significados capazes de estabelecer uma unidade interpretativa, a recorrência a esses espaços aglutinadores traduz os sentimentos dos seus representantes e revelam a vontade de seus autores. Esse processo inculcador, todavia, dependia - como estamos insistindo desde o início desta discussão - da disciplinarização/sujeição dos sentidos por meio de uma arquitetura sensitiva capaz de habituá-los em sua cotidianidade. E, nesse caso, a prática ritual aparece geralmente como primeiro componente dessa arquitetura, sugerindo aos sentidos, no processo de disciplinarização e habituação, as imagens recorrentes que tornam essenciais determinados valores e cristalizam um imaginário de unidade e, por corolário, de brasilidade. A comemoração, por exemplo, do primeiro aniversário do Estado Novo, em 10 de novembro de 1938, no Colégio Catarinense, já nos sugere esse entendimento sobre a força "arregimentadora" do ritual, a ponto de ganhar as páginas do Diário Oficial do Estado.

Às nove horas, no galpão desportivo daquele modelar estabelecimento de ensino, teve lugar a solenidade, que constou do seguinte: Hino à Bandeira, por todos os alunos; Saudação à Bandeira, do Sr. Inspetor Antenor Moraes pelo aluno Temístocles Muniz; Discurso pelo Padre Bertoldo Braun, Prefeito Geral; Minha Terra, poesia pelo aluno José Gallotti e Hino Nacional, por todos os alunos; a seguir foi pronunciado o inspirado e patriótico discurso pelo Padre Prefeito Geral. (Ginásio Catarinense, 1938, p. 74)

Como podemos perceber, essa solenidade esteve revestida de um ritual, com o inspirado e patriótico discurso do padre prefeito, insinuando que

Getúlio Vargas harmonizou todos os membros da nação; legislou instituições sábias para o operário, evitando que ele caísse nas garras do comunismo; legislou a proteção da propriedade; legislou normas necessárias tendentes a integrar, no corpo da nossa nacionalidade, elementos ainda estranhos a ela; e regulamentou a entrada de estrangeiros, impedindo que o Brasil se tornasse um viveiro de anarquistas. [...] Por isso, juremos hoje fidelidade à nossa Pátria e juremos ódio de morte ao nosso maior inimigo, ao comunismo. [...] Oxalá Deus guie a mão de Getúlio Vargas para continuar nesta obra grande que lhe está confiada, moralizando cada vez mais nosso país. (Diário Oficial do Estado, 1938, p. 3)

Não seria por outra razão que a estrutura curricular contemplaria esses propósitos, explicando-os dentro do entendimento nacionalista. $\mathrm{O}$ aumento das cargas horárias para o ensino de história, geografia e língua nacional e a introdução das disciplinas de economia política e sociologia indicavam o eixo no qual girava o currículo escolar. 
Nesses espaços curriculares, preferencialmente, os alunos deveriam ser moldados nos princípios morais e religiosos da pátria brasileira, reconhecendo, por meio dos estudos da ciência econômica e da sociologia, o direito à propriedade e o respeito à família e ao Estado (Ginásio Catarinense, 1942, p. 12). Mas o solene ritual - ao confirmar e sacralizar esses princípios morais - dava aos sentidos uma sensação de ordenamento, normalidade e "habituidade", já que a reação coletiva condicionava à percepção uma única e determinada realidade.

Outros tantos atos solenes de igual força ritual se sucederam ao longo do período, enchendo os sentidos com o espetáculo de imagens, tal como foi na inauguração da nova ala em 1940 ou da nova portaria em 1942, nas comemorações do IV Centenário da Companhia de Jesus, nas formaturas, nas festas das congregações marianas ou numa simples cerimônia de inauguração de um retrato.

A solenidade de inauguração de um quadro de padre José de Anchieta e de retratos do ex-governador do estado Vidal Ramos, de Duque de Caxias e do Almirante Barroso expressou uma estreita relação entre a propaganda estado-novista e o uso que se fez desses quadros e retratos.

Às 15 horas realizou-se no Ginásio Catarinense a inauguração de um quadro do padre José de Anchieta, oferta de um grupo de ex-alunos daquele estabelecimento e dos retratos a óleo do sr. coronel Vidal Ramos, fundador do Ginásio, do Duque de Caxias e do Almirante Barroso, estando presentes os srs. dr. Nereu Ramos, interventor federal no Estado; D. Joaquim Domingues de Oliveira, arcebispo metropolitano. (Ginásio Catarinense, 1940, p. 14)

O descerramento do quadro do padre jesuíta José de Anchieta aconteceu nas comemorações do IV Centenário da Companhia de Jesus. Essa prática ritual conferia à cerimônia uma força regularizadora que implicava relação com um passado apropriado. Afinal, menos lembrado foi o próprio fundador da Companhia de Jesus, Inácio de Loyola. Ficaram por conta das figuras de Anchieta, Nóbrega e Vieira todos os discursos e pronunciamentos oficiais, o que traduzia o momento forte de efervescência nacionalista. Buscava-se nos jesuítas lusitanos, e somente neles, uma forjada continuidade de práticas tipicamente luso-brasileiras, consubstanciadas na raça, na língua portuguesa e na fé católica. Apropriava-se de uma história em vista daquilo que se queria legitimar e construir no presente. E, nas paredes do colégio, retratava-se o ideal de brasilidade.

Anchieta passara a ser, no discurso do cronista, "o pioneiro da consciência nacional e o símbolo da fé, da ciência, da virtude, do patriotismo" (Ginásio Catarinense, 1940, p. 16), antes mesmo do nascimento da ideia de Brasil ou de nação brasileira. Eis, pois, aí, uma linguagem que contém armadilhas e ao mesmo tempo uma função prática e social. Como falamos anteriormente, essa imagem de Anchieta habituaria os sentidos a uma forma de perceber e conceber a realidade. Para o momento estado-novista de criação de uma nova identidade nacional, "a juventude [do Colégio Catarinense] que aprendia o temor de Deus, que se formava no cultivo das ciências, não podia esquecer, que era dever de todos e imposto por Deus, o amor à pátria, 
o amor íntegro, o amor capaz de todos os sacrifícios" (Ginásio Catarinense, 1940, p.16). A glorificação de Anchieta, ou melhor, dessa arquitetura sensitiva permitida pelo rito, deveria levar o jovem a reconhecer quais eram as origens do Brasil e a renovar o batismo nacional (idem, p. 37). Por isso, Getúlio Vargas - ao considerar nacionais as homenagens à Companhia de Jesus, por motivo do quarto centenário de sua fundação (decreto n. 6.355, de 27 de setembro de 1940) - declarara que a Companhia de Jesus teria realizado a base da civilização nacional e possibilitado a existência de uma cultura nacional do mais alto sentido, imprimindo à sociedade em formação a disciplina moral que perdurou (idem, p. 1). Mas o ritual de descerramento e os discursos queriam dizer mais que isso. Se dos jesuítas lusitanos do passado dependeu o Brasil, dos colégios inacianos, agora, dependeriam o progresso e a vitória da pátria.

A formação forjada por uma arquitetura visual dos sentimentos nacionais pensada como um processo de sujeição a uma cultura, a uma língua e a uma fé comum - deveria ser espalhada e ensinada nesses núcleos de ensino. Qualquer prática que atravancasse o avanço dos ideais de nacionalização estava de antemão condenada. Fazia-se acreditar que a ordem estado-novista realizaria os anseios do bem comum, salvando a população brasileira dos inimigos reais e imaginados. Desse ponto de vista, o conceito de democracia não estaria definido nas razões de uma maioria popular autônoma, mas na postura disciplinar de um governo autoritário e forte, que dizia ser capaz de realizar e agrupar o ideal de justiça social desejado por todos.

No princípio da autoridade deveria ser encontrada a forma de dar ritmo compassado aos movimentos sociais, de reprimir os ânimos exaltados dos políticos, de assegurar, por meio da educação escolar, os sentimentos, as ideias e os valores comuns da brasilidade. Esse princípio, para desespero de um outro - o da liberdade -, emergia de uma matriz arbitrária, repressora e autoritária. A liberdade, nessa cosmovisão, corromperia o sonho, o projeto. A sociedade anterior teria dado mostras dessa deficiência. E ela era considerada decadente e caótica exatamente pela liberdade que dava. Para se imprimir um novo ritmo à vida nacional, apresentou-se como necessário um governo forte, austero, que encarnasse supostamente as inspirações da nação brasileira. E a ditadura de Vargas deveria confirmar essa expectativa, ao ressignificar o princípio da autoridade.

A visita de Getúlio Vargas à capital do estado de Santa Catarina em março de 1940 deu projeção a essa imagem de otimismo e de transformação social, centrando a esperança da coletividade na formação de uma pátria unida, moderna e próspera. Ele representava - para os alunos do Colégio Catarinense que se fizeram presentes à solenidade - o corajoso combatente da alteridade anômala e o símbolo da ordem estabelecida, legitimada e confirmada pela Igreja católica. Essa visita foi cercada de todo o poder envolvente de ritualização, num impulso forte de adesão, como se estivesse processando naqueles dias a completude de um destino. Dois anos depois,

[...] com a presença do Exmo. Sr. Interventor Federal e altas autoridades militares, eclesiásticas e dos alunos, realizou-se no dia 08 de setembro de 1942 a solenidade de inauguração da nova portaria do Ginásio. [...] E convidado pelo Diretor, 
dirigiu o Sr. Dr. Nereu Ramos ao salão de honra para descerrar o retrato de Getúlio Vargas, fazendo-o sob acalorada salva de palmas. Ainda convidado pelo Diretor, o Sr. Coronel Valdir Lopes da Cruz descerrou o retrato do Sr. Dr. Nereu Ramos, bem como Monsenhor Harry Bauer que descerrou o retrato do Exmo. Arcebispo Metropolitano, grande amigo e benfeitor do Ginásio, D. Joaquim Domingues de Oliveira. (Ginásio Catarinense..., A Gazeta, 1942 p. 4)

Nas cerimônias cívico-religiosas e nas festas dos congregados marianos do colégio - de modo semelhante aos grandes desfiles do Dia do Trabalho com a presença do presidente da República -, Getúlio Vargas, assim como todos os seus colaboradores, passava a ser visto como um abnegado herói que guiava e convocava a todos para ajudar a construir uma nação e levantar do marasmo e da insônia os possíveis desesperançados. Nas paredes do colégio também estava retratado seu olhar penetrante e inflexível de brasilidade. Vê-lo ou sentir-se visto por ele naquela cotidianidade - já que a imagem comporta essa dupla funcionalidade - era situar o jovem no espaço conflituoso do poder, deixando aos sentidos a sensação - porque também está motivada pelo rito - de encontrar nesse retrato a segurança e a estabilidade sociais. O que quer dizer, segundo Bronislaw (1985, p. 300), que

[...] as situações conflituais entre poderes concorrentes estimulam a invenção de novas técnicas de combate no domínio do imaginário. Por um lado, estas visam à constituição de uma imagem desvalorizada do adversário, procurando em especial invalidar a sua legitimidade; por outro lado, exaltam através de representações engrandecedoras o poder cuja causa defendem e para a qual pretendem obter o maior número de adesões.

O fato de sentir-se habituado a ver esse retrato ou aquele quadro - o que é permitido pelos sentidos numa determinada arquitetura sensitiva - confere segurança e tranquilidade ao esforço de todos de se sentirem integrados e reconhecidos naquele espaço. Por isso, a ascensão à presidência da República era de fato cada vez mais vista como necessária para que se pudesse destruir o mal que espreitava a nação. Nas palavras do cronista do colégio, encontramos a construção dessa imagem do herói salvador da pátria:

O Estado, em especial, o Estado Novo, orientado pelo notável chefe que é Getúlio Vargas, encara de frente, em todos os setores, o problema da família brasileira. As leis trabalhistas se baseiam nas encíclicas papais e tendem a garantir ao operário o salário-família, base da família numerosa. O Estado Novo realmente é o pai do Brasil: a ele o nosso apoio irrestrito. O que Getúlio Vargas fez para facilitar e harmonizar todos os membros da nação não há palavra que exprima dignamente. (Ginásio Catarinense, 1943, p. 13)

Realmente não havia palavra que exprimisse. Por essa razão, esses discursos teriam que se transformar necessariamente em imagens, capazes de materializar instantaneamente o conteúdo epistêmico de suas próprias intenções. Getúlio era 
visto como o herói a quem Deus abençoou por meio de seus representantes na Terra, dando-lhe o poder de ser chefe de uma nação. A fabricação desse herói, por retratos e quadros que se repetiam e se reproduziam nos espaços, exigia uma parcela de espontaneidade criadora e outra parcela de construção intencional. A referência ao líder-herói trazia a ideia de ordem, de disciplina e de progresso. Mas a missão que the cabia, a de restaurar e ordenar uma nação, deveria estar em conformidade com os critérios da moral cristã. Era a unidade nacional e religiosa que se buscava. Portanto, o organismo social teria de funcionar adequadamente, sem as improvisações e as "anomalias" que geravam a diferenciação.

Ninguém poderia ficar de fora dessa empreitada. Os quadros e retratos descerrados - ao invadir a cotidianidade daquele colégio - indicavam mesmo o grau de comprometimento de alguns sujeitos. Mas todos deveriam assumir integralmente o ideal de brasilidade, sem se opor ou resistir. As imagens suspensas nas paredes estavam lá para dizer isso aos sentidos. Os padres do Colégio Catarinense, formadores do caráter e dos sentidos, teriam a função primeira de alargar os sentimentos nacionais e de criar uma identidade homogênea entre seus alunos. Cada moço deveria reconhecer-se em Vargas, considerado autêntico defensor dos interesses da nação brasileira. Enfim, deveriam esses padres colaborar para a ordem, vendo-se como responsáveis diretos pela execução dessas metas.

Portanto, a constituição de uma arquitetura sensitiva no espaço escolar deveria ajudar - como uma verdadeira maquinaria de propaganda e controle - a compor a trama estado-novista e a promover a domesticação/disciplinarização dos sentidos. As ritualizações e as técnicas de reprodutibilidade das imagens tiveram a função de divulgar, generalizar, uniformizar, habituar e manter os sentidos em alerta constante e, portanto, de ligá-los, de condicioná-los ao sistema de controle. Eis a força dessa arquitetura!

Mesmo assim, ainda alguém nos poderia perguntar: "Por que, afinal, as paredes ouvem e falam?". E nossa resposta seria: porque as paredes se personificam, metamorfoseiam-se diante dos olhos, transformam-se em arquitetura viva e sensitiva ao suspender e mostrar, com toda a sua carga de intencionalidade, determinadas imagens. Eis a arte de disciplinar os sentidos!

\section{REFERÊNCIAS}

Benjamim, Walter. A obra de arte na era de sua reprodutibilidade. In: Magia e técnica, arte e política. São Paulo: Brasiliense, 1994.

Bronislaw, Bazcko. Imaginação social. In: ENCICLOPÉDIA EINAUDI. Lisboa: Imprensa Nacional; Casa da Moeda, 1985.

Capanema, Gustavo. Exposição de motivos da lei orgânica do ensino secundário. In: Nóbrega, Vandick Londres da. Enciclopédia da legislação do ensino. Rio de Janeiro: Revista dos Tribunais, 1952. 
Chaui, Marilena; Franco, Maria Sylvia Carvalho. Ideologia e participação popular. São Paulo: CEDEC; Rio de Janeiro: Paz e Terra, 1979.

Colégio Catarinense. Relatório. Florianópolis: [s.n.], 1944.

Dallabrida, Norberto. A fabricação escolar das elites: o Ginásio Catarinense na Primeira República. Florianópolis: Cidade Futura, 2001.

Diário Oficial do Estado. Florianópolis, p. 3, 14 nov. de 1938.

Foucault, Michel. Vigiar e punir. Petrópolis: Vozes, 1987.

Ginásio Catarinense. Relatório. Florianópolis: [s.n.], 1933.

. Relatório. Florianópolis: [s.n.], 1938.

IV Centenário da Companbia de Jesus. Florianópolis: [s.n.], 1940.

. Relatório. Florianópolis: [s.n.], 1942.

. Relatório. Florianópolis: [s.n.], 1943.

Ginásio Catarinense inaugura nova portaria. A Gazeta. Florianópolis, 11 set. 1942. Lenharo, Alcir. A sacralização da política. São Paulo: Papirus, 1986.

Máximo, João; Didier, Carlos. Noel Rosa: uma biografia. Brasília: Linha Gráfica/ UnB, 1990.

Nóbrega, Vandick Londres da. Enciclopédia da legislação do ensino. Rio de Janeiro: Revista dos Tribunais, 1952.

Oliveira, Doming Joaquim Domingues de. O problema da instrução (carta pastoral). Florianópolis: Cisne, 1920.

Rosa, Noel. Três apitos. 1933. Disponível em: <http://www.youtube.com/ watch?v=d5DwmMcrFkE >. Acesso em: 1 abr. 2014.

Toвias, José Antônio. História da educaşão brasileira. São Paulo: IBRASA, 1986.

\section{SOBRE O AUTOR}

Rogério Luiz Souza é doutor em história pela Universidade Federal do Paraná (UFPR). Professor da Universidade Federal de Santa Catarina (UFSC). E-mail: rogerio.souza@ufsc.br 